\title{
Settlers, Sell-outs and Sons of the Soil: The Creation of Aliens in Zimbabwe and the Challenge for Higher Education
}

\author{
Munyaradzi Hwami \\ University of Alberta \\ hwami@ualberta.ca
}

\begin{abstract}
The contemporary colonial world is witnessing struggles for domination and existence that have led to exclusion of some groups on the basis of parameters defined by the powerful. This contribution observes practices and policies of belonging and exclusion developing in Zimbabwe and argues that higher education should take the lead in discussing and proposing citizenship education that would produce cosmopolitan patriots, responsible and tolerant citizens. The discussion is a critical discourse analysis of dominant colonial forces of authoritarian nationalism and neoliberalism supplemented by personal experience and engagement with students and faculty at the Great Zimbabwe University. What has been observed is the failure of civil society and state led programmes in this endeavour and the honours rests with higher education institutions to develop citizenship education rooted in ideals that critique hegemonic discourses. This demands a change in perspectival foci and this study advances the adoption of anti-colonial liberationist perspectives as one of the options if an end to classification of citizens as aliens and patriots is to come to an end.
\end{abstract}

\section{Introduction}

Zimbabwe belongs to the Zimbabweans, pure and simple ... white Zimbabweans, even those born in the country with legal ownership of their land, have a debt to pay. They are British settlers, citizens by colonization. (President Robert Mugabe, in an interview with CNN's Christine Amanpour, September, 2009)

You must understand that as Zimbabweans and as Africans ... we are trying to come up with one thinking, one vision of survival as a race because we are attacked as a race. ... The problem is very fundamental, and that is upbringing... 
Our children, who vote against their own heritage, who vote against their own people, who vote together with whites, who fight on the side of whites, they don't know the difference between the White man's world view and our world view, the White man's agenda and our agenda. (ZANU PF media monologue from the University of Zimbabwe participating on a prime time television programme called National Ethos, as cited in Gandhi \& Jambaya, 2002, p. 11)

The issue of citizenship in Zimbabwe as a post-independent society has not been publicly debated and, as has been observed in other societies, it is at the centre of the agenda of the resolution of the national question as it relates to the issues of race relations, settler-native binaries, and ownership of resources like mines and land, and control of national public discourse (Mamdani, 2001). Like in other southern African states that obtained independence from European rule after an armed struggle, the former liberators in Zimbabwe consider participation in the war as one of the main determinants of being an authentic Zimbabwean (Blair, 2002; Bond \& Manyanya, 2003; Bratton \& Masunungure, 2008; Meredith, 2007; NdlovuGatsheni, 2009b). During the war of liberation, white Rhodesians, most of whom were from Anglo-Saxon speaking countries such as Britain, Canada and Australia were perceived as enemies of the people of Zimbabwe, foreigners who had come to steal Zimbabwe's wealth (Dunn, 2009; Muzondidya, 2007). It should however be noted that in official documents and pronouncements, the two main liberation movements, the Zimbabwe African National Union Patriotic Front (ZANU PF) and the Zimbabwe African Peoples Union (ZAPU) publicly advocated a multi-racial society and this was corroborated by Prime Minister Mugabe's policy of reconciliation in 1980. But the propaganda machinery as was engineered by the freedom fighters in the rural areas pointed out the objectives of the war as driving out the whites (Rhodesians) and then retake the country's resources such as land (farms), and minerals (Hughes, 2010). This resonated with the peasants who wanted to regain the land their forefathers lost to the Europeans (Bond, 2001; Moyo \& Yeros, 2007; 2011; Scarnecchia, 2006), but as was observed by NdlovuGatsheni (2009b) there was no unanimous position on whether Zimbabwe was to be a multiracial society or not and that should explain the conflicting perspectives in current debates. There was no space in higher education institutions to debate and critique the state of the nation as deliberate effort was made to instil among the people, particularly the youth, the revolutionary 
foundation of the independent Zimbabwe and the unparalleled role of ZANU PF.

The first decade of independence saw the promulgation of the policy of reconciliation by President Robert Mugabe's (then Prime Minister) government and this was accompanied by a fairly smooth transition from Rhodesian racist society to a multi-racial society that was led by a black majority government. This policy was acclaimed by many all over the world with Robert Mugabe being seen as an example of African enlightened leadership and honorary degrees from North American and European universities were bestowed on the former guerrilla leader (Rogers, 2007; Romano, 2008). Higher education institutions were multi-racial and attracted foreign students. However, by the end of the 1990's there was growing evidence that the honeymoon was coming to an end and the economic reforms that were adopted at the behest of the International Monetary Fund (IMF) and the World Bank were causing untold suffering (Chisvo, 1993; Danzereau, 2005; Gono, 2008; Hwami, 2011; Hwami \& Runhare, 2009; Kariwo, 2007; Mali, 1995; Shizha, 1998) and the people were beginning to blame Mugabe and his government, the revolution, it was said, had lost its course (Astrow, 1983; Ayittey, 1992). To Mugabe and his government, there was "unfinished business" (Hammar \& Raftopoulos, 2003, p. 37) which had to be concluded and this largely entailed wholesome transfer of the economy from the hands of the minority whites to the majority blacks. The land reform programme from around 2000 is widely recognized as the date for this Afro-radical nationalist turn also referred to as the Mugabe turn (Ndlovu-Gatsheni, 2009b). The same period also witnessed the emergence and rise of the opposition Movement for Democratic Change (MDC), and there has always been strong evidence that it has the sympathy and support of the white community in Zimbabwe and western countries. The higher education community, particularly students, aligned and supported the MDC much to the disdain of ZANU PF that saw the opposition as puppets of the British.

It can be reasonably argued that it was after the 2000 and 2002 elections, in which many people voted for the MDC in the parliamentary and presidential elections, that Mugabe began to divide Zimbabweans into traitors, puppets, sell-outs, enemies of the nation versus patriots and authentic national subjects. Those who had voted for the MDC became categorized as traitors, sell-outs, puppets and enemies of Zimbabwe. Only those who voted for and supported the ruling ZANU-PF party qualified as patriots and authentic national subjects (Ndlovu-Gatsheni, 2008a). Some would point that the exclusion of certain sections had been practised since independence. Narratives on post-independent Africa are littered with cases of tribalism/ethnicity that have 
shaped government and state administrative structures (Berman, 1998; Ekeh, 1990; Fanon, 1963). There is no doubt that President Robert Mugabe's rule of over three decades has witnessed his Zezuru or Mashonaland area developing than other regions in the country. Some of the best post-secondary institutions are located in Mashonaland, while regions such as Masvingo, Matebeleland and Manicaland seem to have been left behind. However, ZANU PF elites are scattered all over the country and this presentation addresses citizenship from a national perspective and does not intend to reduce its analysis to one specific tribe/ethnic group. This article, however acknowledges the existence of grievances among some ethnic groups such as the Karanga and the Ndebele whose perception has been that the ZANU PF government has intentionally failed to address their bread and butter grievances.

The purpose of this paper is to examine the contested issue of citizenship by posing the following questions: Can this be conceptualized as racism in reverse and therefore a policy that is incongruent with modern global trends? Is this just dictatorial tendency by an unpopular nationalist party bent on retaining power? Is this a brave subaltern response to the forces of economic subjugation and immizeration of the poor contained in neoliberal globalization principles? The paper addresses these questions and proposes that higher education in Zimbabwe should delink itself from and try to theorize outside the hegemonic discourses of neoliberalism and nationalism. If black empowerment and indigenization programmes underway are government efforts to delink the economy from Europe and North America, higher education should go beyond operating from this authoritarian nationalist paradigm, and adopt "a double critique" (Mignolo, 2000, p. 66) of both ZANU PF authoritarian nationalism and Euro-America neoliberalism. Higher education should not be used as a state instrument to exclude certain groups in the Zimbabwean society from being citizens of the country. Just as the land issue was and is continuously on the agenda of unfinished business in Zimbabwe, so is the issue of citizenship.

This presentation is a critical discourse analysis of hegemonic discourses, specifically ZANU PF Afro-radicalism and neoliberalism, from a socio-political economy perspective. I situate this paper within my Western (Canadian) theoretical and practical experience of citizenship as well as lived experience of the Zimbabwean situation since 2000. I have aligned myself with anti-colonial perspectives in order to give meaning to the unfolding crisis of citizenship in Zimbabwe. I am in this presentation as a participant having experienced exclusion 
as a member of the university community in Zimbabwe and also as a researcher or constructor of theoretical understandings of the citizenship conundrum.

The article starts by considering a conceptualization of citizenship in Zimbabwe by utilizing different perspectives. The following section considers how higher education has been employed as a state instrument to support the ruling party's Afro-radical conceptualization of citizenship. The final segment argues that higher education institutions such as universities should theorize and propose citizen friendly policies and practices.

\section{Conceptualizing and Theorizing Citizenship in Zimbabwe}

Citizenship in post-independence Africa has become a cause of civil national conflicts

and in some countries, such as Rwanda and the Democratic Republic of the Congo, catastrophic civil wars. Zimbabwe is one of the very few countries in Africa that have enjoyed long and extended periods of "peace and stability", a perception many in higher education will vehemently contest. The advent of neoliberal economic policies in 1990 when the country adopted IMF and World Bank informed structural adjustment programmes (Chakaodza, 1993; Shizha, 2006) marked the beginning of deterioration in social services that the Zimbabwean people had come to expect since the dawn of independence in 1980. Policy changes in higher education meant that students were now responsible for the payment of their education as contained in neoliberal policy frameworks (World Bank, 1998; Federici, 2002; Hwami, 2010). The consequent hardships faced by those in higher education made universities and colleges fertile grounds for the development of anti-ZANU PF government views and the emergence of the MDC as a serious contender in national politics. ZANU PF considered this as a betrayal to the efforts that brought an end to British colonial rule and students and staff in higher education were seen as traitors, supporters of the MDC and its Western allies and sponsors. This construction of the opposition thus placed them outside of a legitimate national narrative, and thrust it into the territory of an alien, un-African and treasonous force that justified the coercive use of the state in order to contain and destroy such a force. Mugabe's description of the MDC aptly captures this characterisation of the opposition and its supporters:

The MDC should never be judged or characterised by its black trade union face; by its youthful student face; by its salaried black suburban junior professionals; never by its rough and violent high-density lumpen elements. It is much deeper than these human 
superficies; for it is immovably and implacably moored in the colonial yesteryear and embraces wittingly or unwittingly the repulsive ideology of return to white settler rule. MDC is as old and as strong as the forces that control it; that converge on it and control it; that drive and direct; indeed that support, sponsor and spot it. It is a counterrevolutionary Trojan horse contrived and nurtured by the very inimical forces that enslaved and oppressed our people yesterday. (Mugabe, 2001, p. 88)

The opposition having been located as an alien political force, the full coercive force of the state was brought to bear on those regarded as "unpatriotic" and "puppets of the West." It should be noted that colonial Zimbabwe was a terrain of racism, where the black people were not recognized as citizens of the country (then known as Rhodesia), but second class people, servants of the civilized whites of European origin. The current economic and political world order, which benefits the western/northern countries, can be used to explain the resurgence of what can be described as racism in reverse as practised in Zimbabwe today. When Mugabe described white Zimbabweans as “citizens by colonization" (Amanpour, 2009), and Zimbabweans who vote together with whites are considered as lost, this shows that race has become an issue at the centre of the country's socio-economic development agenda. This was aptly put across by President Mugabe:

We extended a hand of reconciliation to people like Ian Smith (former Rhodesian prime minister) and said that if you want to stay in this country and obey our laws under Black majority rule with you coming under them, stay. Was that right or wrong? I think that today at conscience I say on behalf of the party we made a mistake. When you forgive those who do not accept forgiveness, when you show mercy to those who are hardhearted, when you show non-racialism to die-hard racists; when you show a people with a culture - false culture of superiority based on their skin-and you do nothing to get them to change their personality, their perceptions, their mind, you are acting as a fool. (Gandhi \& Jambaya, 2002, p. 9)

The abrupt turn in policy by President Mugabe's government, from reconciliation in 1980 to a racist anti-white stance after 2000 has been an involving endeavour for many scholars and pundits of what has come to be described as the Zimbabwean question. The white commercial farmers were categorized as settlers (settler was not a legal identity but an insurgent assertion, a libel lurked back by natives at the core beneficiaries of colonial 
rule) rather than citizens and President Mugabe declared that "our party must strike fear into the heart of the white man" (Ndlovu-Gatsheni, 2006, p.7). Consequently a number of white commercial farmers lost their lives having been attacked by ZANU PF militias (Blair, 2002; Muzondidya, 2007). It was declared that Zimbabwe was for the Zimbabweans just as Africa is for Africans, thus refusing to acknowledge the existence of white Africans. President Robert Mugabe was pronouncing what the people expected in 1980, but then he disappointed them with the adoption of the policy of reconciliation. Mandaza (as cited by Ndlovu-Gatsheni, 2009b) concluded that reconciliation was "the mourn of weak, even when pronounced from position of apparent moral and political superiority over oppressors and exploiters of yesterday" (p. 1142). To ordinary people, "justice meant nothing less than a turning of the tables at the expense of the settler and in favour of the native" (Mamdani, 2001, p. 31).

According to Ndlovu-Gatsheni (2006) the Zimbabwean situation reflects the risks involved in any African attempt to defy neoliberal globalization policies and should be seen within the broader context of African response to modern forms of colonialism.

The Zimbabwean crisis can be situated within the current global environment, which is characterized by triumphant neoliberalism. ...Neoliberalism is provoking combative spirit of localism, concretely taking the form of a resurgence of nationalism in Africa. ...To sort out an economy lacuna fashioned by settler racism, ZANU PF used nativist racism that first of all denied the white settler Zimbabwean citizenship in order to take the land from him. (p. 13)

This perspective seems to borrow from Walter Mignolo's argument of delinking the south from global capitalism as a way of attaining real progress in these societies (Mignolo, 2000). The view that the adoption of racist policies in Zimbabwe was a result of Western pressure and humiliation of Robert Mugabe has been argued convincingly from a number of quarters (See Moyo \& Yeros, 2007). Nativism developed out of an emphasis of the idea of a unique African identity founded on membership of the black race. The black race through the three processes of slavery, colonization and apartheid became alienated from itself (selfdivision), experienced dispossession, subjugation, humiliation and nameless suffering (Mbembe, 2002). To a certain extent President Mugabe feels humiliated by Britain and her western allies. 
Mugabe's relationship with the West was rosy in the 1980s and 1990s when he was a frequent visitor to Western capitals and was a recipient of honorary degrees from Western universities but today he is under travel restrictions and can only enter the western world under the auspices of the United Nations. To a certain extent this humiliation can be seen as the driving force behind the culture of vengeance against Britain's kith and kin (white Africans) and all those who sympathise with them. Moisi's (2009) analysis concluded that such emotions/culture of humiliation can lead one to sheer irrationality and even sometimes to violence.

Humiliation is the injured confidence of those who have lost hope in the future; your lack of hope is the fault of others, who have treated you badly. When the contrast between your idealized and glorious past and your frustrating present is too great, humiliation prevails. (p. 5)

ZANU PF's idea of a Zimbabwean citizen is seen as political and racist. Anti-colonial perspectives and analysis (Dei, 2010; Fanon, 1963; Mignolo, 2000) essentialize race and class as the main areas of hegemonic oppression and any racist practice should be condemned, regardless of the perpetrator. It is said Phineas Chihota, a deputy cabinet minister, provided a purely nativist definition of an indigenous Zimbabwean. According to him an indigenous person had to have a rural home. Thus to race being a criterion for including and excluding people as Zimbabweans was added having a rural home as a sign of being 'indigenous'. Since the time that urban people voted overwhelmingly for the MDC in the 2000 and 2002 parliamentary and presidential elections, urban Zimbabweans have increasingly been presented as not belonging to the nation. During an election rally in Bindura in 2000, President Mugabe singled out the residents of the high density suburb of Mbare Musika in Harare as "undisciplined, totemless elements of alien origin" (Ndlovu-Gatsheni, 2009b, p. 1152). This shows that besides whites as clearly being excluded from being Zimbabwean citizens, certain pockets of the population, notably students and people living in urban areas were singled out as not belonging. In other words all those who voiced opposition to the ruling party or simply demonstrated sympathy for the opposition parties were considered unpatriotic and consequently not true Zimbabweans. Evidence shows that they could expect no protection of the law especially from ZANU PF elements (Blair, 2002; Bond, 2010; Bratton \& Masunungure, 2008).

On the other hand supporters and sympathisers of President Mugabe view him as an African patriot and a revolutionary (Mazire, 2011; Phimister \& Raftopoulos, 2004) who is 
aiming to achieve genuine development and advancement of black Africans through purposeful discrimination. From this perspective citizenship and belonging to Zimbabwe has to be understood within the broad claims of the underdeveloped people of the global South. This could be going "beyond a Eurocentric critique of modernity and Eurocentrism" (Mignolo, 2002, p. 57), but practically disengaging Zimbabwe from global capitalism. Such positioning is a very appealing moral standpoint that has been exploited by the Zimbabwean government to its advantage as it defends its dictatorial tendencies towards its own citizens. Any foreign criticism of the ruling party is warded off as imperialist interference. At the Earth Summit in Johannesburg in 2002, President Mugabe echoed this view while attacking the then British Prime Minister, Tony Blair, "So Blair, keep your England and let me keep my Zimbabwe" (Ndlovu-Gatsheni, 2009b, p. 1139). The high participation of students and staff in civic organization and opposition politics has been widely observed (Chikwanha, 2009; Chimanikire, 2009; Zeilig, 2008) and hence the harsh treatment they have been receiving from ZANU PF.

Thus what is observed in Zimbabwe today is a categorization of citizens with whites of European descent being considered as non-citizens, settlers and agents of British imperialism. Opposition parties such as the Movement for Democratic Change (MDC), civic organizations and non-governmental organizations are seen by the government as traitors or sell-outs, puppets of the West and agents of regime change. ZANU PF and its supporters are the genuine "sons of the soil" (Dunn, 2009, p. 113), "patriots, revolutionaries and liberators" (Mazire, 2009) and hence heirs to the country's resources and consequently beneficiaries of government's indigenization and black empowerment policies.

\section{Citizenship and Education in Zimbabwe}

It is generally acknowledged that all forms of education involve citizenship training (Abdi, Ellis \& Shizha, 2005). However, some nations have specific programmes aimed at developing a certain kind of citizenry (Banks, 2001; Torres, 1998). In Zimbabwe the aim is to produce a graduate who is patriotic to the nation (Barnes, 2004; Chikwanha, 2009; Raftopoulos, 2004; Tendi, 2008) and the same focus is found in universities (Ranger, 2004). There is also a course called National Strategic Studies (NSS) that is compulsory in higher education institutions such as teachers' colleges and polytechnics (Ministry of Higher and Tertiary Education, 2002; 2006). The central theme in these courses and subjects is for learners to appreciate the revolutionary history of the country so that they can appreciate and respect the efforts of those 
who fought for the independence of the country. The government seems to be driven by the notion that nationalism is the sine quo non of stability and development. The government and political leadership view these courses as key instruments for repelling the forces of Western imperialism that seek regime change in Zimbabwe (Hwami \& Runhare, 2009; Tendi, 2008; Ranger, 2004). Students and faculty are not comfortable with these studies and there has been open rebellion against taking these courses or just taking them to fulfill a requirement without really being engaged. The government is attempting to develop what they describe as a "patriotic citizen" (Bull-Christiansen, 2004; Ranger, 2004). The driving understanding behind the government standpoint is that history and NSS would assist the media in recreating a patriotic Zimbabwean youths to "reassert the sovereignty of our state in absolute rejection of imperialist machinations of divide and rule, exploitative globalization, marginalization, manipulation and control of our political projections in pursuit of both our national and continental unity" (Muzeza, 2006, p. 7). Patriotic history is a vital instrument for political consciousness and an arena through which the ruling party and government ideology can be projected and protected among the young generation or 'born free' Zimbabweans (Hwami \& Runhare, 2009). In another sense, patriotism to the country equals loyalty to the ruling party.

Accompanying the patriotic version of history in Zimbabwe have been open definitions of Zimbabweans that exclude those that are seen as unpatriotic. Besides the obvious candidates, whites and opposition supporters, the government openly labels the diaspora as foreign. The diaspora and how the Zimbabwean Government relates with it, has brought out an interesting dynamic around systematic discrimination based on geographic location as well as perceived political sympathies. The Zimbabwean diaspora is thus found in a hard place, where they are prone to discrimination of a racial nature based on their descent, while at the same time, there is no reasonable action that can be taken by their home state, because it abhors the fact that they left in the first place, in search of economic and political stability (Lewanika, 2011). Because of perceptions of the diaspora as hostile to the state, the diaspora is then effectively shut out from political processes like the constitution making process and elections.

\section{Citizenship and the Challenge for Higher Education}

The discourse of patriots, revolutionaries and liberators heavily informed by the authoritarian and exclusivist ideology of nationalism has emerged as a challenge to the realization of any form of tolerance of difference and competing views in Zimbabwe. But higher 
education institutions in Zimbabwe, should not dismiss nativism as an empty ideology as advised by Ndlovu-Gatsheni (2008a; 2009b). The fight for independence against the Rhodesians was centred and strengthened by the uniting factor of nationalism that made it possible for the different ethnicities to imagine themselves as a community, despite some glaring differences. Furthermore, in the contemporary times of political and economic turmoil, it should be noted that "the employment of autochthony discourses is an attractive response (one of several possible) to the ontological uncertainty of the postmodern/postcolonial condition” (Dunn, 2009, p. 115). Considering the fact that higher education is state controlled and funded, it would not be feasible to demand higher education to extricate itself from the state. However, it is still expected to operate within epistemological parameters that delink Zimbabwe's higher education from all forms of coloniality.

It has been widely observed that at the core of citizenship education are value orientations that underpin popular rule, such as political tolerance and a desire for political equality and accountability (Appiah, 1997; Gibson \& Gouws, 2003; Inglehart 1997; Torres, 1998).

"Citizenship or civics education is construed broadly to encompass the preparation of young people for their roles and responsibilities as citizens and, in particular, the role of education in that preparatory process" (Kerr, 1999, p. 4). Democratic citizens unlike autocratic subjects (Mamdani, 1996) or patrimonial clients (Fox, 1990) tolerate a diversity of political opinion, support principles of universal suffrage, and demand that leaders respond to mass needs (Bratton, 2005). The major stumbling block that makes it difficult to realize such citizenship education is the environment of nationalist dictatorship that has been developed since the days of the armed struggle. Higher education institutions such as universities are found categorized by the ZANU PF government as critical and strategic, and hence should be administered by Zimbabwean patriots and this generally means ZANU PF members. The significance of universities was underlined in 1981 by the then Prime Minister, Robert Mugabe, "To paraphrase that famous aphorism about generals and war: higher education is too important a business to be left entirely to deans, professors, lecturers and University administrators" (Chideya, Chikomba, Pongweni \& Tsikirayi, 1981, p. 6).

The debate surrounding citizenship and citizenship education in post-independent Zimbabwe should be placed within the context of the aftermath of the much-hated European colonial rule that saw whites labelled as settlers and foreign oppressive alien invaders 
(Adejumobi, 2001; Ndlovu-Gatsheni, 2008b; Osaghae, 2005) and the contemporary triumphalism of neoliberalism despite its devastating impact on the living standards of ordinary people. The Zimbabwean scenario is well captured by the outstanding Zimbabwean historian Sabelo J. Ndlovu-Gatsheni:

At the end of the Cold War, Zimbabwe gradually manifested a growing shift from the developmental nationalism of the 1980s into the Afro-radicalism and nativism of the 2000s together with its emphasis on cultural nationalism. This shift happened in tandem with the emergence of a radical civil society that began to embrace and articulate postCold War neo-liberal ideologies of good governance, democracy and human rights. These developments were happening within a local context of Zimbabwe's fast descent into an unprecedented economic crisis at the beginning of the 2000s and a global context of increasing international pressure on peripheral governments to embrace liberal democracy and its notions of rights. The nationalist liberation project was being pushed into the defensive by the triumphant forces of neo-liberal globalization. (NdlovuGatsheni, 2009a, p. 68)

This means before talking about the form and content of citizenship education, those in higher education in Zimbabwe should be conscious of the issues and forces at play in current world politics. There is the need to appreciate that "a discussion of citizenship cannot be divorced or separated from the polemics of democracy, human rights, the rule of law and social justice. These areas are sites of struggle within the context of individual Africans and collectivities such as civil society associations with most still fighting for basic political rights" (Abdi, Shizha \& Ellis, 2005, p. 460). Neoliberalism and authoritarian nationalism have developed to be two competing ideologies providing paths to Africa's better future and dominating the contexts of citizenship (Hwami, 2010, 2011; Hwami \& Runhare, 2009). "The current products of these epistemological narratives on Zimbabwe are two competing and sometimes overlapping imaginations of liberation namely; neo-liberal postmodernist and the radical liberationist approaches" (Ndlovu-Gatsheni, 2008b, p 6). It therefore follows that any form of meaningful programme that purports to be citizenship education, should be grounded in strong theories of Zimbabwe's cultural and ontological historicity. This then means the fundamental challenge higher education should tackle is to develop epistemological foundations from which to argue. Like in nearly all other parts of Africa, Zimbabwean intellectual and liberation initiatives have 
found it very difficult to "unthink" the epistemologies created by enlightenment intellectuals and to "reproduce itself outside these relations" (Quijano 2007, p. 169). The end product has been "scholarship by analogy" that has pervaded some of the influential intellectual works in and on Africa (Mamdani, 1996; Ndlovu-Gatsheni, 2008b). The first step in ending universities and African, specifically Zimbabwean, intellectuals from mimicking Western scholarship is to come up with ideas that are informed by neither neoliberalism nor nativism. In other words a new paradigm should be developed.

This paradigm is being contested by liberationist approach whose starting point of narration of the African story is contestation of coloniality in its various disguises and accommodates nativism and Afro-radicalism as it consistently potholes coloniality and pushes for the 'next liberation' after the failure of the first and second phases of liberation. This liberationist paradigm is currently at its formative phase and is antagonising under the heavy weight of triumphant neo-liberalism and globalisation as it struggles to creatively combine national, democratic and social justice questions into a single new democratic consensus that is simultaneously ranged against global colonial hegemony and local/domestic authoritarianism and oppression. (Ndlovu-Gatsheni, 2008b, p. 6)

The task of those in higher education is to develop a relevant local epistemological paradigm to situate and inform the debate on citizenship. To date there has been a call for the adoption of the philosophy of unhu/ubuntu (Battle, 2009). It is not merely a reference to humanity/personhood, but an indication of human conduct in relation with others (Venter, 2004; Shizha, 2009; Swanson, 2007). Edward Shizha noted that in Zimbabwe "unhu/ubuntu embodies all the invaluable virtues that society strives toward maintaining harmony and the spirit of sharing among its members" (Shizha, 2009, p. 144). As a philosophical thread of African epistemology, "unhu/ubuntu focuses on human relations, attending to the moral and spiritual consciousness of what it means to be human and to be in relationship with others" (Swanson, 2007, p. 55). There is a general perception emerging within sub-Saharan Africa that the adoption of unhu/ubuntu as a guiding perspective or theory by institutions and academics may help contribute to modern challenges such as the terror of neoliberal globalization and authoritarian nationalism (Ramose, 2003; Swanson, 2007). This line of thinking has support of notable scholars such as Gupta (1998) and Ashis Nandy (cited by Peet \& Hartwick, 2009) who "argues 
for a critical traditionalism that tries to marshal the resources provided by inherited cultural frames for purposes of social and political transformation" (p. 239). Thus effective and culturally sensitive programs of citizenship education should be formulated that both formally and informally educate the public about political processes as well as their fundamental rights, complemented by the important virtues of democracy.

The thrust of the Zimbabwean government has been to produce a patriotic citizen, one who is conscious enough to understand and appreciate the blood sacrifices of those who perished in the struggle for independence and in the process acknowledge the revolutionary foundations of the nation (Chitate, 2005; Ministry of Higher and Tertiary Education, 2002; Ministry of Youth Development, Gender and Employment Creation, 2000; Ndlovu-Gatsheni 2009a; Mazire, 2011; Ranger, 2004, 2008). Such an approach is seen as

a political expression of a single dominant and relatively homogeneous ethnic group 'native African' or 'sons of the soil - with pre-eminent rights over the country's land and other resources. This represents a rigid and exclusionary definition of citizenship and nationhood. (Muzondidya, 2007, p. 325)

Without denying the heroic sacrifices of the gallant liberation fighters, there has been open resistance from students and faculty to the imposition of this ideological approach but unfortunately there has not been any discussion of alternatives. The challenge for higher education is to disapprove this narrow and exclusivist version of patriotism and advocate "moral cosmopolitanism" (Varouxakis, 2008, p. 4) that involves a fellow-feeling with the whole of mankind. Along the same line Walter Mignolo (2000) argues:

I am proposing cosmopolitanism, critical and dialogic, emerging from the various spatial and historical locations of the colonial difference. The problem, then, is not to accommodate cosmopolitanism to cultural relativism, but to dissolve cultural relativism and to focus on the coloniality of power and the colonial difference produced, reproduced, and maintained by global designs. (p. 741)

This entails constructing Zimbabwean ideas, such as unhu/ubuntu, and utilize them to deconstruct oppressive and colonial ideologies of Afro-radicalism and nativism and neoliberalism that are currently dominant. Critical and dialogic cosmopolitanism demands yielding generously toward diversity as a universal and cosmopolitan project in which everyone participates. There should be concerted effort to build awareness among students to accept that 
cosmopolitanism and democracy can no longer be articulated from one point of view, an Afroradical perspective. There is need for "a theory of multicultural democratic citizenship" (Torres, 1998 , p. 9) that will take seriously the task to develop a theory of democracy that will help to ameliorate and if possible eliminate the social differences, inequality and inequity pervasive in Zimbabwe. Such a theory, which I strongly believe should be informed by the Southern African philosophy of unhu/ubuntu, must deconstruct the fantasies of security and certainty inherent in autochthony discourses and expose the deceptive and seductive attractiveness of neoliberalism. In other words this liberation philosophy (Dunn, 2009; Ndlovu-Gatsheni, 2008b) should be a "double critique" of neoliberalism and nationalism, "a project of delinking", some form of "scholarly transformation" (Mignolo, 2008, p. 6) that intentionally aims at coming up with “conscientizing education” (Mbele, 2011). The end product would be citizenship education construed broadly to encompass the preparation of young people for their roles and responsibilities as citizens (Kerr, 1999) despite their diversity. Furthermore, when properly constituted, "citizenship should provide common or equal rights and benefits to those considered citizens in the state" (Adejumobi, 2001, p. 154). This means as long as one is a Zimbabwean, being white, diaspora, of Malawian or Zambian origin, belonging to the opposition or working for a Western non-governmental organization, should not be issues of consideration.

\section{Conclusion}

Higher education institutions, particularly universities, are the most strategically positioned in the current Zimbabwean political set-up to help develop citizenship education that can produce "cosmopolitan patriots" (Appiah, 1997; Mignolo, 2000; Varouxakis, 2008). Most other seemingly civic responsibilities have been taken over by Western non-governmental organizations and some have questioned the legitimacy of civil society;

Civil society is a middle-class/elite project that does not approximate the broad range of popular forces. Second, the emergent civil society (as opposed to embedded one) is largely a creation of global capitalism that has continued to finance it in its concubinage with non-governmental organisations (NGOs). Third, NGOs are nothing but important agents of globalisation and Western hegemony in Africa. Finally, civil society today does not have the national appeal and 
conviction that distinguished the anti-colonial alliances of the old. (Osaghae, 2005, p. 17)

Such strong views against civil society and non-governmental organizations have been expressed from many quarters (Kapoor, 2011; Edwards, 2008; Escobar, 1995; Dibie, 2008; Petras \& Veltmeyer, 2001). This leaves higher education institutions with the moral mandate to undertake the responsibility of shouldering citizenship education that would produce a responsible Zimbabwean, one who is responsible to his social milieu and the whole world. Such education should involve equipping students with knowledge and understanding, skills and aptitudes, values and dispositions that enable them to participate actively and sensibly as adult citizens. Higher education in Zimbabwe should strive to produce a citizen who is aware of the wider world and has a sense of their own role as a world citizen, respects and values diversity, has an understanding of how the world works economically, politically, socially, culturally, technologically and environmentally, is outraged by social injustice, is willing to act to make the world a more equitable and sustainable place, participates in and contributes to the community at a range of levels from the local to the global. (Davies, 2008, p. 1)

The above entails a change in perspectival foci and this contribution sees the adoption of anti- colonial perspectives (Dei, 2010; Kapoor, 2009), the liberative perspective (NdlovuGatsheni, 2008b) or joining forces with South Asian subaltern studies, with "negative critique" as is advanced by some philosophers from Africa, and with "double critique," that is, of Afroradicalism and Western fundamentalism at the same time (Mignolo, 2002, p. 91). Citizenship education rooted in ideals that critique hegemonic discourses such as authoritarian nationalism and neoliberalism is the challenge higher education in Zimbabwe should take up. The epistemic challenge is to deconstruct and reconstruct ideas for the continued decolonization of Zimbabwe and the achievement of decoloniality because under existing conditions, some sections of the population have been "de-oracized and subalternized" (Ndlovu-Gatsheni, 2008b, p. 2), they have become illegal foreigners in their own country. 


\section{References}

Abdi, A. A., Ellis, L. \& Shizha, E. (2005). Democratic development and the role of citizenship education in sub-Saharan Africa with a case focus on Zambia. International Education Journal, 6(4), 454-466.

Adejumobi, S. (2001). Citizenship, rights, and the problem of conflicts and civil wars in Africa. Human Rights Quarterly, 23, 148-170.

Amanpour, C. (2009). Mugabe denies blame for Zimbabwe woes. Retrieved from http://edition.cnn.com.

Appiah, K. A. (1997). Cosmopolitan patriots. Critical Inquiry, 23(3), 617-639.

Astrow, A. I. (1983). Zimbabwe: A revolution that lost its way? London: Zed Books.

Ayittey, G. B. N. (1992). Africa betrayed. New York: St Martin's Press.

Banks, J. A. (2001). Citizenship education and diversity: Implications for teacher education. Journal of Teacher Education, 52(1), 5-16.

Barnes, T. (2004). Reconciliation, ethnicity and school history in Zimbabwe 1980-2002. In B. Raftopoulos \& T. Savage (Eds.), Zimbabwe: Injustice and political reconciliation (pp. 140-159). Capetown: Institute for Justice and Reconciliation.

Battle, M. (2009). Ubuntu. New York: Seabury Books

Berman, B. J. (1998). Ethnicity, patronage and the African state: The politics of uncivil nationalism. African Affairs, 97(388), 305-341.

Blair, D. (2002). Degrees in violence: Robert Mugabe and the struggle for power in Zimbabwe. London: Continuum.

Bond, P. (2001). Radical rhetoric and the working class during Zimbabwean nationalism's dying days. Journal of World Systems Research, 7(1), 52-89.

Bond, P. \& Manyanya, M. (2003). Zimbabwe’s plunge. Harare: Weavers Press Ltd.

Bratton, M. (2005). Poor people and democratic citizenship in Africa. Michigan: Michigan.

Bull-Christiansen, L. (2004). Tales of the nation: Feminist nationalism or patriotic history? Defining national history and identity in Zimbabwe. Uppsala: Nordiska Afrikainstitutet

Chakaodza, A. U. (1993). Structural adjustment in Zambia and Zimbabwe: Reconstructive or deconstructive? Harare: Third World Publishing Company.

Chideya, N. T., Chikomba, C. E. M.A., Pongweni, J. C. \& Tsikirayi, L. C. (Eds.). (1981). The role of the University and its future in Zimbabwe: International Conference Papers. 
Harare: Harare Publishing House.

Chikwanha, A. B. (2009). Higher education and student politics in Zimbabwe. In D. P. Chimanikire (Ed.), Youth and higher education in Africa (pp. 79-108). Dakar: CODESRIA

Chimanikire, D. P. (Ed.). (2009). Youth and higher education in Africa. Dakar: CODESRIA. Chisvo, M. (1993). Report on government spending on social services and the impact of Structural adjustment in Zimbabwe. Harare: UNICEF.

Chitate, H. (2005). Post-independent Zimbabwe's new Ordinary level history syllabus 2166: A crisis of expectations. Zimbabwe Journal of Educational Research, 17(3), 234-257.

Dansereau, S. (2005). Between a rock and a hard place: Zimbabwe's development impasse. In H. Melber (Ed.), Zimbabwe-The political economy of decline (pp. 7-26). Goteborg: Nordiska Afrikainstitutet.

Davies, L. (2008). Global citizenship education. Encyclopedia of Peace Education. Retrieved from http://www.tc.edu/centers/epe/.

Dei, G. J. S. (2010). Fanon, anti-colonialism and education: An introduction. In G. J. S. Dei (Ed.), Fanon and the counterinsurgency of education (pp. 1-10). Rotterdam: Sense Publishers.

Dibie, R. A. (2008). Introduction: NGOs and human development in Africa: Theory and model for collaboration. In R. A. Dibie (Ed.), Non-governmental organizations and sustainable development in sub-Saharan Africa (pp. 1-37). Plymouth: Lexington Books.

Dunn, K. C. (2009). Sons of the soil and contemporary state making: Autochthony, uncertainty and political violence in Africa. Third World Quarterly, 30(1), 113-127.

Edwards, M. (2008). Have NGOs made a difference? From Manchester to Birmingham with an elephant in the room. In A. J. Bebbington, S. Hickey \& D. C. Mitlin (Eds.), Can NGOs make a difference: The challenge for development alternatives (pp. 26-57). London: Zed Books.

Ekeh, P. P. (1990). Social anthropology and two contrasting uses of tribalism in Africa. Comparative Studies in Society and history, 32, 660-700.

Escobar, A. (1995). Encountering development: The making and unmaking of the Third World. Princeton: Princeton University Press.

Fanon, F. (1963). The wretched of the earth. New York: Grove Press 
Federici, S. (2002). The recolonisation of African education. In S. Federici, G. Caffentzis \& O. Alidou. (Eds.), A thousand flowers: Social struggles against structural adjustment in African Universities (pp. 19-24). Asmara: Africa World Press.

Fox, J. (1990). The challenge of rural democratization: Perspectives from Latin America and the Philippines. London: Franl Cass.

Gandhi, D. \& Jambaya, L. (2002). Towards a national agenda on Zimbabwe Broadcasting Corporation: Vision 30 Revisited. Harare: Media Monitoring Project of Zimbabwe.

Gibson, J. \& Gouws, A. (2003). Overcoming intolerance in South Africa: Experiments in democratic persuasion. New York: Cambridge University Press.

Gono, G. (2008). Zimbabwe's casino economy: Extraordinary measures for extraordinary challenges. Harare: ZPH Publishers.

Gupta, A. (1998). Postcolonial developments: Agriculture in the making of modern India. Durham, NC: Duke University Press.

Hammar, A., Raftopoulos, B. and Jensen, S. (2003). Zimbabwe's unfinished business: Rethinking land, state and nation. In A. Hammar, B. Raftopoulos \& S. Jensen (Eds.), Zimbabwe's unfinished business: Rethinking land, state and nation in the context of crisis (pp. 1-23). Harare: Weaver Press.

Hughes, D. M. (2010). Whiteness in Zimbabwe: Race, landscape, and the problem of belonging. New York: Palgrave Macmillan

Hwami, M. (2010). Neoliberal globalization, ZANU PF authoritarian nationalism and the creation of crises in higher education in Zimbabwe. Journal of Alternative Perspectives in the Social Sciences, 2(1), 57-89.

Hwami, M. (2011). Understanding the crisis in higher education in Zimbabwe: Critical explorations. In D. Kapoor (Ed.), Critical perspectives on neoliberal globalization, development and education in Africa and Asia (pp. 103-120). Rotterdam: Sense Publishers.

Hwami, M. \& Runhare, T. (2009). The ideological role of education in the clash between nation state conservatism and globalization. The case of Zimbabwe. Journal of Educational Studies, 8(1), 34-56.

Inglehart, R. (1997). Modernization and postmodernization: Cultural, economic and political 
change in 43 societies. Princeton: Princeton University Press.

Kapoor, D. (2012). Human rights as paradox and equivocation in contexts of Adivasi (original dweller) dispossession in India. Journal of Asian and African Studies, 47(4), 1-17.

Kariwo, M. T. (2007). Widening access in higher education in Zimbabwe. Higher Education Policy, 20, 45-59.

Kerr, D. (1999). Citizenship education: An international comparison. International review of curriculum and assessment archives. London: Qualification and Curriculum Authority.

Lewanika, M. (2010). Contemporary and sophisticated forms of discrimination in Zimbabwe: A thorn in our back. Retrieved from ww.thezimbabwean.co.uk/humanrights/36302/contemporary-and-sophisticated-forms-of-discrimination-in-zim-a-thorn-inour-back.html

Mali, N. (1995). The impact of structural adjustment on education in Zimbabwe. Stockholm: Uppsala University Unit of Development Studies.

Mamdani, M. (1996). Citizen and subject: Contemporary Africa and the legacy of late colonialism. Princeton: Princeton University Press.

Mamdani, M. (2001). When does a settler become a native? Citizenship and identity in a settler society. Pretext: Literacy and Cultural Studies, 10(1), 63-73.

Mazire, I. (2011). Patriots, revolutionaries, liberators. Retrieved from http://www.zimpapers.co.zw/index.php?option=com_content\&view=article\&id=1999:pat riots-revolutionaries-liberators \& catid=37:top-stories \&Itemid=130.

Mbele, V. (2010, December). Conscientizing education is black young people's only hope. Pambazuka News, 508. Retrieved from http://www.pambazuka.org/en/category/comment/69279.e 508.

Mbembe, A. (2002). African modes of self-writing. Public Culture, 14(1), 239-273.

Meredith, M. (2007). Mugabe: Power, plunder and the struggle for Zimbabwe. New York: Public Affairs.

Mignolo, W. D. (2000). The many faces of cosmopolis: Border thinking and critical cosmopolitanism. Public Culture, 12(3), 721-748.

Mignolo, W. D. (2002). The geopolitics of knowledge and the colonial difference. The South Atlantic Quarterly, 101(1), 57-96.

Mignolo, W. D. (2008). Delinking: The rhetoric of modernity, the logic of coloniality and the 
grammar of decoloniality. Cultural Studies, 21(2/3), 1-75.

Ministry of Education, Sports and Culture. (2006). Education Amendment Bill. Harare:

Government Printers.

Ministry of Higher and Tertiary Education. (2002). National Strategic Studies Syllabus: Harare:

Government Printers.

Ministry of Youth Development, Gender and Employment Creation. (2000). The National Youth Policy of Zimbabwe. Harare: Government Printers.

Moisi, D. (2009). The geopolitics of emotion: How cultures of fear, humiliation and hope are reshaping the world. London: Bodley Head.

Moyo, S. \& Yeros, P. (2007). Intervention: The Zimbabwe question and the two lefts. Historical Materialism, 15(3), 171-204.

Moyo, S. \& Yeros, P. (2011). After Zimbabwe: State, nation and region in Africa. In S. Moyo \& P. Yeros (Eds.). Reclaiming the nation: The return of the national question in Africa, Asia and Latin America (pp. 78-104). New York: Pluto Press.

Mugabe, R. (2001). Inside the Third Chimurenga. Harare: Government of Zimbabwe.

Muzeza, D. (2006). Youths: Agents of social change in Africa. Retrieved from http://allafrica.com/stories/200605170571.html

Muzondidya, J. (2007). Jambanja: Ideological ambiguities in the politics of land and resource ownership in Zimbabwe. Journal of Southern African Studies, 33(2), 325-341.

Ndlovu-Gatsheni, S. J. (2006). The nativist revolution and the development conundrums in Zimbabwe. ACCORD Occasional Paper Series, 1(4), 1-40.

Ndlovu-Gatsheni, S. J. (2008a). Patriots, puppets, dissidents and the politics of inclusion and exclusion in contemporary Zimbabwe. EASSRR, XXIV(1), 81-108.

Ndlovu-Gatsheni, S. J. (2008b). Nativism and the debate on African public sphere in postcolonial Africa: Reflections on a problematic 'Reverse-Discourse.' Paper presented under the panel Nationalism, public sphere and citizenship in Africa at the Council for the Development of Social Science Research in Africa (CODESRIA)'s 12th General Assembly: Governing the African Public Sphere, Yaoundé, Cameroon.

Ndlovu-Gatsheni, S. J. (2009a). Making sense of Mugabeism in local and global politics: "So Blair, keep your England and let me keep my Zimbabwe”. Third World Quarterly, 30(6), 1139-1158. 
Ndlovu-Gatsheni, S. J. (2009b). Africa for Africans or Africa for natives only? New nationalism and nativism in Zimbabwe and South Africa. Africa Spectrum, 1, 61-78.

Osaghae, E. E. (2005). The State of Africa's Second Liberation, Interventions, 7(1), 1-20.

Peet, R. \& Hartwick, E. (2009). Theories of development: Contentions, arguments and alternatives. New York: The Guilford Press.

Phimister, I. \& Raftopoulos, B. (2004). Mugabe, Mbeki and the politics of anti-imperialism. Review of African Political Economy, 101, 385-400.

Quijano, A. (2007). Coloniality and modernity/rationality. Cultural Studies, 21(2-3), 168-178. Raftopoulos, B. (2004). Nation, race and history in Zimbabwean politics In B. Raftopoulos \& T. Savage (Eds.), Zimbabwe: Injustice and political reconciliation (pp. 160-175). Capetown: Institute for Justice and Reconciliation.

Ramose, M. B. (2003). Globalization and ubuntu. In P. H. Coetzee \& A. P. J. Roux (Eds.), The African Philosophy Reader (pp. 626-650). New York: Routledge.

Ranger, T. O. (2004). Nationalist historiography, patriotic history and the history of the nation: the struggle over the past in Zimbabwe. Journal of Southern African Studies, $30(2), 215-234$.

Ranger, T.O. (2008). Lessons of Zimbabwe: Letters. London Review of Books, 30(24). Retrieved from http://www.lrb.co.uk/v30/n24/letters

Rogers, I. (2007). Zimbabwe President Mugabe faces rebuke, retraction of honorary degrees. Diverse Issues in Higher Education, 24(11), 12-13.

Romano, C. (2008). Dishonorary degrees. The Chronicle of Higher Education, 54 (44) Retrieved from http://chronicle.com/article/Dishonorary-Degrees/19228/

Scarnecchia, T. (2006). The fascist cycle in Zimbabwe, 2000-2005. Journal of Southern African Studies, 32(2), 221-237.

Shizha, E. (1998). Cost recovery and its implications for student teachers in government education colleges in Zimbabwe. Zimbabwe Journal of Educational Research, 10(2), 154-173.

Shizha, E. (2006). Continuity or discontinuity in educational equity: Contradictions in structural adjustment programs in Zimbabwe. In A. A. Abdi, K. P. Puplampu \& G. J. S. Dei. (Eds.), African education and globalization: Critical perspectives (pp. 187-212). Oxford: Lexington Books. 
Shiza, E. (2009). Chara chimwe hachitswanyi inda: Indigenizing science education in Zimbabwe. In D. Kapoor \& S. Jordan (Eds.), Education, participatory action research, and social change: International perspectives (pp. 139-153). New York: Palgrave Macmillan.

Swanson, D. M. (2007). Ubuntu: An African contribution to (re)search for/with a humble togetherness. Journal of Contemporary Issues in Education, 2(2), 53-67.

Tendi, B. (2008). Patriotic history and public intellectuals critical of power. Journal of Southern African Studies, 34(2), 379-396.

Torres, C. A. (1998). Democracy, education and multiculturalism: Dilemmas of citizenship in a global world. Presidential address to the Annual Meeting of the Comparative International Education Society, Buffalo, New York.

Varouxakis, G. (2008). Cosmopolitan patriotism in J. S. Mill's political thought and activism. Revne detudes benthamiennes, 4, 1-36.

Venter, E. (2004). The notion of ubuntu and communalism in African educational discourse. Studies in Philosophy of Education, 23, 149-160.

World Bank. (1988). Education in Sub-Saharan Africa: Policies for adjustment, revitalization, and expansion. Washington, DC: World Bank Lexington Books.

Zeilig, L. (2008). Student politics and activism in Zimbabwe: The frustrated transition. Journal of Asian and African Studies (43)2, 215-237. 